\title{
The Please Strategy Effect to Improve Paragraph Writing Skill At Universitas of Ibrahimy
}

\author{
Annisa Kurnia Asri \\ English Department, Social and Humanity Science Faculty, University of Ibrahimy \\ Email Correspondence : annisakurniaasri@gmail.com
}

\section{A R T I C LE INF O}

Keywords:

English Language Skill

Writing

Writing Skill

PLEASE Strategy

\section{Article History:}

Received : 21 December 2021

Accepted : 25 January 2022

Published : 14 February 2022

\section{A B S T R A C T}

Writing skill in English is a productive skill that involves several components such as topic, ideas, main ideas, supporting ideas, sentence structure, grammar, diction, and writing technique. University students must be able to compose well-structured and elaborated academic writing. They are urged to create credible writings in the academic field and one of the strategies that can be used is the PLEASE strategy. PLEASE strategy is a writing strategy that has six steps namely: Pick, List, Evaluate, Activate, Supply, End. Therefore, this research aims to find the effect of the PLEASE strategy to improve English writing skills of the university of students in semester 4 at the English Department, Faculty of Social Science and Humanities University of Ibrahimy Situbondo. The findings of this research were drawn by using Z-test. It shows that the PLEASE strategy can significantly improve students' writing skills. PLEASE strategy can help students to think systematically and critically using all those 6 steps. 


\section{Introduction}

Writing without guidelines or mapping can distract the writer's focus on the topic being discussed. The writing might be not well structured and systematically written. It can also lead to a writer-reader gap when what is meant by the writer cannot be well understood by readers. In this study, the researcher wanted to implement the PLEASE strategy and tried to find out whether this strategy can help students to improve their writing skills or not. PLEASE strategy is an acronym of (Pick, List, Evaluate, Activate, Supply, End). The acronym can help students to remember the steps to write effectively and efficiently. Students can apply this strategy to compose any idea in a written form easily just by memorizing the acronym.

This research aims to find the effect of PLEASE strategy to improve English writing skills of the University of students semester 4 English Department, Faculty of Social Science and Humanities University of Ibrahimy Situbondo. The students were taking Writing II class which focused on how to develop paragraph writing. The result of this study was expected to help students or academics decide what kind of strategy fits their needs in composing academic writing. Furthermore, scholars at the University of Ibrahimy can get a picture of how the PLEASE strategy was implanted and how its effect might be helpful for students as well as the teachers or lecturers.

(Zemach \& Rumisek, 2003) states that there are six steps in writing. Those six steps are a) selecting a topic, b) gathering and compiling data or ideas for sub-topics, c) arranging sub-topics coherently, d) drafting and writing, e) revising and f) re-revising and finalizing. Every step mentioned above needs time and high order thinking ability so that the writing can be called academic writing. In academic writing, steps and guidance are very important to help the writers to compose sentences into paragraphs. The paragraphs, later on, must be elaborated into an essay. The essays then can be compiled into scientific work or maybe research. Thus, in this research, the researcher wanted to focus on academic paragraph writing as the basis for the students to compose academic writing that will always be needed in higher education.

PLEASE strategy (Pick, List, Evaluate, Activate, Supply, End) is a strategy that uses a mnemonic strategy. This strategy helps students in writing arranges students to follow guidelines or steps in writing a paragraph since the steps or guidance easily just by remembering the acronym of PLEASE. An acronym is a part mnemonic device that can help students to recall what they have learned easily (Loewen \& Sato, 2017). PLEASE strategy also helps students to associate or access their prior knowledge as well as the information they have gathered in composing academic writing.

PLEASE strategy is a kind of road map to develop a writing product using an acronym that can be remembered and applied easily(Aminatun et al., 2019) . PLEASE strategy can be used as a tool to make the students able to express their ideas in written form coherently from beginning to concluding sentences or paragraphs. Moreover, the researcher believes that the PLEASE strategy will make students get engaged to compile their outline, draft, feedback, revision, and final product.

PLEASE strategy has been applied in some previous studies. This strategy has attracted many researchers to apply it in teaching writing and to see how effective this strategy is. The result of a study conducted by (Aminatun et al., 2019), (Milford \& Harrison, 2010), (Siringoringo et al., 2017), (Nasution, 2018), (APRILLIYANTI et al., 2019), (Liza \& Refnaldi, 2013) and other researchers showed that the PLEASE strategy can improve students' writing skill. Moreover, (Aminatun et al., 2019) concluded that the PLEASE strategy is more effective than the Guided Writing strategy specifically to those students who own higher linguistics intelligence. A study carried out by (Milford \& Harrison, 2010)showed that the PLEASE strategy can help students with special needs 
to improve their writing and to focus on the topic in their writing. The students even demonstrated a positive response toward the strategy and showed the ability to write systematically.

Siringringo (2017) conducted a study about the PLEASE strategy for junior high school students. The result showed that the PLEASE strategy can significantly improve students' writing skills after they had 6 meetings. The average score the students obtained has increased from 35.46 to 77.4. Another experimental study was done by (Nasution, 2018) and it showed the same. PLEASE strategy has been proven to significantly improve junior high school students' writing skills compared to conventional ones. Two other studies were also conducted by (Liza \& Refnaldi, 2013) and (APRILLIYANTI et al., 2019) who concluded that the PLEASE strategy can help junior high school students to improve their writing skills.

\section{Methods}

This research is quantitative research using a Pre-experimental design. The data gathered will be explained using descriptive explanation meanwhile the data will be analyzed to be able to draw conclusions. This pre-experimental method used in this research uses One Group Pre-test and post-test design based on some factors. Some of the factors are: 1) in 2018 offering, there was only one class of English department students, 2) the time and facility such as class are limited, students need to take turning to use the facilities, and 3) the progress that students made in writing skill could be measured so that the teacher or facilitator can get a picture how this strategy was being implemented.

\section{Result}

\subsection{Inferential Statistics}

This study collected writing skill scores from 30 English Language Teaching departments using a writing rubric. The pre-test and post-test scores were analyzed to find out the mean score as represented by the curve below:

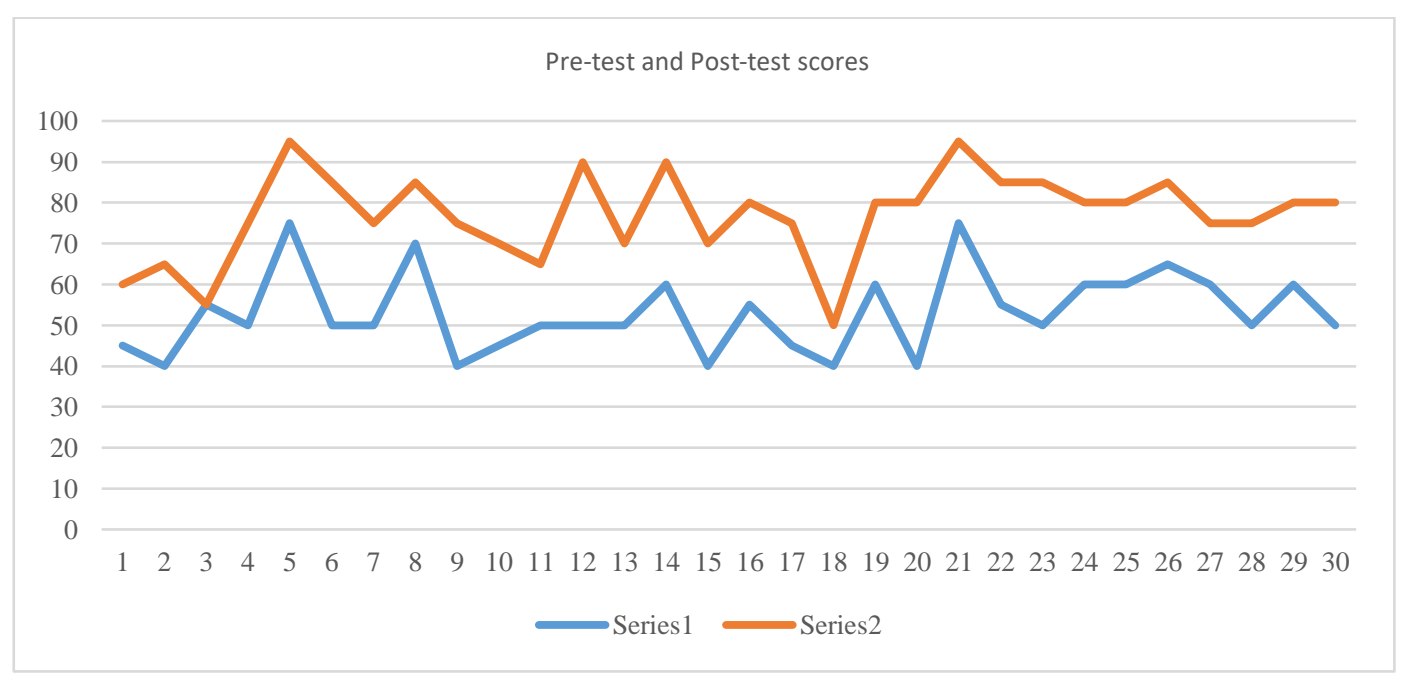

Fig. 1. Pre-test (blue line) and Post-test (orange line)

Based on the curve above it can be concluded that the students' mean score has increased from 53.2 to 77. The implementation of the PLEASE strategy also helped to improve each student's writing skill except for one student that didn't show improvement. Overall, the whole students 
could improve their writing skills. Moreover, to investigate how significant this strategy was, a Ztest one-tailed was used to analyze the score.

\subsection{The Result of Z-test One-tailed Analysis}

(Gunawan, 2015) explains that hypothesis testing using a single mean with more than 30 subjects can be done by using z-TEST. The formula of the Z-test is:

$$
\mathrm{Z}=\frac{\overline{\mathrm{y}}-\mu}{\frac{\sigma}{\sqrt{\mathrm{n}}}}
$$

Note:

$\bar{y}=$ post-test score mean

$\mu=$ pre-test score mean

$\sigma=$ standard deviation

$\mathrm{n}=$ sample size

Based on the scores obtained, the mean of post-test is 77 and the mean of pre-test is 53.2 . Standard deviation is 9.7 as calculated by using Microsoft Excel and the sample or subjects of the study is 30 mahasiswa. Therefore, the data can be analyzed this way:

$$
\mathrm{Z}=\frac{77-53,2}{\frac{9,7}{\sqrt{30}}} \rightarrow \mathrm{Z}=\frac{23,8}{1,77} \rightarrow \mathrm{Z}=13,44
$$

The $\mathrm{Z}$ score is +13.44 and the significance level is +1.65 . Thus it can be concluded that the $\mathrm{Z}$ score is bigger than the $\mathrm{Z}$ table so that the null hypothesis is refused and the alternative hypothesis is accepted. In other words, this study shows that there is a positive significant effect between PLEASE strategy implementation and students' writing skills.

\section{Discussion}

Based on the findings above, it can be concluded that the alternative hypothesis is accepted. Therefore it can be concluded that the PLEASE strategy can improve students' writing skills since the $\mathrm{Z}$ score shows a positive score. This finding is absolutely supported by previous studies and theories about mnemonic that have been discussed earlier. Previous studies by(Aminatun et al., 2019), (Milford \& Harrison, 2010), (Siringoringo et al., 2017)(Nasution, 2018), and (Liza \& Refnaldi, 2013) showed the same result with this finding. In addition, the implementation of the PLEASE strategy can be used for students at any level and need.

\section{Conclusion}

PLEASE strategy is proven to improve students' writing skills in this study. PLEASE strategy is one of the mnemonic strategies where students can use the acronym to help them remember the steps or guidance in writing. concludes that mnemonic can help students to remember and make use of their prior knowledge to be linked with their current work or study.(Milford \& Harrison, 2010) agree that the PLEASE strategy can be implemented for students with special needs too. In addition, this study revealed that almost all students in the English Language Teaching Department of Faculty Social sciences and Humanities, University of Ibrahimy can improve their writing skills based on the pre-test and post-test scores obtained. 


\section{Acknowledgments}

This research is dedicated for my students who are willing to learn and eager to try something new and also Universitas Ibrahimy Sukorejo Situbondo as a place for long-life learning.

\section{References}

Aminatun, D., Ngadiso, N., \& Marmanto, S. (2019). Applying PLEASE strategy to teach writing skill on students with different linguistic intelligence. Teknosastik, 16(1), 34-40.

Aprilliyanti, R., Mirizon, S., \& Anggraini, H. W. (2019). The Use Of Please Strategy To Improve Explanation Text Writing Achievement of The Eleventh Grade Students Of Sma Negeri 5 Palembang. Sriwijaya University.

Gunawan, M. A. (2015). Statistik Penelitian bidang pendidikan, psikologi dan sosial. Yogyakarta: Parama Publishing.

Liza, M., \& Refnaldi, R. (2013). Using PLEASE strategy in teaching writing a descriptive text. Journal of English Language Teaching, 1(2), 436-444.

Loewen, S., \& Sato, M. (2017). The Routledge Handbook of Instructed Second Language Acquisition. In The Routledge Handbook of Instructed Second Language Acquisition. https://doi.org/10.4324/9781315676968

Milford, T., \& Harrison, G. L. (2010). Using the PLEASE strategy with a struggling middle school writer with a disability. Intervention in School and Clinic, 45(5), 326-332.

Nasution, S. N. (2018). The Effect of Using PLEASE Strategy on the Students' Achievement in Writing Descriptive Paragraph at SMPN 1 Bilah Hulu. Universitas Islam Negeri Sumatera Utara.

Siringoringo, A., Aruan, R., \& Sumbayak, D. M. (2017). The effect of PLEASE strategy on the ability of the first year students of SMP N 5 Pekanbaru in paragraph writing. Riau University.

Zemach, D. E., \& Rumisek, L. A. (2003). Academic writing from paragraph to essay. Macmillan. 